\title{
The Benefits of Music and Movement in Early Mathematics
}

\author{
Mohamad Azam Samsudin 1,2, Kamariah Abu Bakar ${ }^{2 *}$, Noorhayati Mohd Noor ${ }^{2}$ \\ ${ }^{1}$ Department of Early Childhood Studies, Universiti Abdul Rahman (UTAR) Sungai Long Campus, Kajang, Malaysia \\ ${ }^{2}$ Faculty of Education, Universiti Kebangsaan Malaysia (UKM), Bangi, Malaysia \\ Email: mohamadazam93@gmail.com, „kamariah_abubakar@ukm.edu.my
}

How to cite this paper: Samsudin, M. A., Bakar, K. A., \& Noor, N. M. (2019). The Benefits of Music and Movement in Early Mathematics. Creative Education, 10, 30713081.

https://doi.org/10.4236/ce.2019.1012231

Received: October 16, 2019

Accepted: November 26, 2019

Published: November 29, 2019

Copyright $\odot 2019$ by author(s) and Scientific Research Publishing Inc. This work is licensed under the Creative Commons Attribution International License (CC BY 4.0).

http://creativecommons.org/licenses/by/4.0/

(c) (i) Open Access

\begin{abstract}
Music and movement is one of the element commonly used in the teaching and learning process in preschool. The purpose of this case study is to explore the use of the music and movement element in the teaching of mathematics in preschool. Purposive sampling was used in the qualitative study. Four teachers from four preschools were selected as participants for this study. The results showed that the use of the music and movement element helped attract children's focus and attention, enhance understanding as well as enrich children's emotion and behavior development. The implication of this study is that preschool teachers should vary their teaching approaches by incorporating the use of the music and movement in their mathematics instruction. Consequently, music and movement are seen to be beneficial including help attract children's attention and interest, improve children's understanding and build children's emotional development.
\end{abstract}

\section{Keywords}

Music, Movement, Teaching and Learning (T\&L), Children,

Mathematics

\section{Introduction}

Preschool education is an important early childhood experience (Yunus, 2014). This level of education is seen as the most important step in the development of the social domain of communication, the formation of gross and fine motor skills, adaptive and social development as preparation to enter the elementary school. This is in line with the first wave of inclusion in the Malaysian Education Development Plan (2013-2025) that outlines various educational programs that play a vital role in driving children's development from preschool to primary 
education.

Preschool education comprises of a variety of teaching and learning (T\&L) strategies including student-centered learning, play, inquiry-based learning, integrated learning, theme-based learning, project-based learning, mastery approaches, contextual approaches and multi-faceted learning intelligence (KSPK, 2017). Learning based on the diversity of intelligence is an integration of the Multiple Intelligence Theory pioneered by Howard Gardner. Intelligence-based learning has eight different types of intelligence including musical intelligence that consists of the ability to recognize rhythm and song (KSPK, 2017). Music is considered one of the teaching activities based on creativity and aesthetics. In preschool, music, movement and drama are seen as important aspects of music education. In fact, music has the potential to support the development of children in various domains through a variety of creative, fun and entertaining activities. In addition, children have the opportunity to showcase their talents and interests according to their level of development.

Research highlighted mathematics as among the most difficult subject. Mathematics is known as a "killer paper" (Azuan, 2003) and children often struggle to comprehend the mathematics concept introduced in classrooms. Researches employed a variety of techniques and approaches to help children learn mathematics in a meaningful yet effective ways including using play approach and utilizing multiple form of representations (Bakar, 2017; Rosli, Goldsby, \& Capraro, 2015; Abdullah, Halim, \& Zakaria, 2014).

The National Council of Teachers Mathematics (NCTM) has suggested teachers to use effective teaching and learning approaches $(\mathrm{T} \& \mathrm{~L})$ in mathematics and engage in music and movement activities when teaching young children (NCTM, 2008). Studies incorporating such teaching and learning approach have proven that applying rhythmic patterns is appropriate and beneficial to mathematical learning (Rauscher et al., 1994; Bilhartz, Bruhn, \& Olson, 1999; Hetland, 2000; Deasy, 2002). However, studies adopting the use of music and movement approach in mathematics are still scarce. Furthermore, most researchers focus more on the benefits of music and movement on language and literacy skills. Therefore, the effects of utilizing music and movement in mathematics should be carried out as this means is well known as one of the effective approaches that is suitable for young children.

\section{Literature Review}

\section{Music and Movement in Preschool Education}

The National Standard Preschool Education (NSPC) curriculum is based on six pillars namely Communication Skills; Spirituality; Attitude and Values; Humanity; Physical and Aesthetic Development, Science and Technology; and Personal Skills. In the Malaysian context, preschool children aged four to six years old are expected to learn knowledge and skills involving reading, writing, speaking, counting and thinking as preparation before entering primary school. The NSPC 
suggested that these important skills to be learnt in a comprehensive and integrated way that encompasses physical, emotional, spiritual, intellectual and social aspects through fun, creative and meaningful learning.

In the process of teaching and learning (T\&L) of preschool education, there are still no specific and most effective teaching approaches and techniques to be applied in a multi-disciplinary classroom (KSPK, 2017). However, music and movement are seen as a commonly used method for preschoolers. This is because music and movement is a fun yet meaningful activities that are appropriate to be employed to children with diverse developmental level, abilities, talents and interests.

In addition, learning through play or also known as "entertainment learning" is the child's natural behavior (Ramlah, 2013). According to Arshad (2012), the activities of singing, storytelling and role playing have the potential to assist teachers in teaching and learning (T\&L) in the classroom. In addition to playing activities, singing is a part of children's life that is inseparable and the children's world will be empty without music. Therefore, music is a creative and innovative way of teaching and learning (Yaakob, 2007, Sustainable 2012).

Music and movement help create a positive learning environment, especially at the preschool level. Pernilla, Wallerstedt, Cecilia, Pramling \& Niklas (2013) consider music as a meaningful experience for children. Elizabeth (2016) also argues that music education is the best source of education. Byi \& Sims (2015) further highlights that music creates a positive environment that help develop self-control and self-efficacy. In addition, creative movement is also part of early childhood education in preschool (Pollatou, Karadimou, \& Gerodimos, 2005). Some studies have reported that creative movements can increase creativity (Garaigordobil \& Berrueco, 2011), improve social skills of preschool children (Lobo \& Winsler, 2006; Williams, 1992), improve well-being (Ells et al., 2009; Frazer, \& Redding, 2007) and contribute to a healthy balance of preschool children (Gallotta, Baldari, \& Guidetti, 2017). Clearly, music and movement facilitated many aspects of children's learning that are helpful in building children's holistic development.

Music is also seen to incorporate kinesthetic, auditory and visual elements (Marsh \& Young, 2016). Music is the art of sound. Music is the melodious sounds produced by the instrument or from one component arranged to produce a good rhythm. Besides that, movement is an absolute necessity for every child and music is seen as helping stimulate this type of movement (Campbell, 2010). Teachers do not only educate children on knowledge and emotional development but also train children in movement (Pica, 2006). Hence, movement is also a form of training for children. Exercise puts the brain in a natural state by controlling mood and coping with stress (Blaydes \& Mitchell, 2010).

It is clear that music and movement have the potential to attract children to mathematical learning and can influence children's development at the preschool level (Cross, Woods, \& Schweingruber, 2009; Gasteiger, 2012; Östergren \& Träff, 2013; Elofsson et al., 2016). In this context, music help develops impor- 
tant mathematical skills including knowing numbers, counting and comparing numbers (Ramani \& Siegler, 2008; Siegler \& Ramani, 2008, 2009; Ramani \& Siegler, 2011; Ramani, Siegler, \& Hitti, 2012; Elofsson et al., 2016). Hence, this study was conducted to explore the use of music and movement in early mathematics in preschool.

\section{Methodology}

This study uses a qualitative approach with case study design. Case studies are chosen because they are in line with exploratory studies (Ahmad Naqiyuddin 2008). This study focuses on the effects of music and movement on children during the teaching and learning process of mathematics.

The purposive sampling technique was used to obtain samples in Selangor schools. According to Ghazali \& Sufean (2016), the sampling technique is intended to be used if it meets all the criteria, properties and contains the information needed to answer the related research questions. The study participants selected for the data collection consisted of four preschool teachers teaching at two different district in Selangor, Malaysia. The selection and determination of locations were selected based on four criteria, namely 1) the location of the study, 2) the information required, 3) the credibility and quality of the secure data, and 4) the close relationship that can be established between researchers and the study participants (Marshall \& Rossman, 2011).

In this research, the researcher used several methods to collect as much descriptive data as possible to get an accurate picture of the teaching and learning process (T\&L). Observations, interviews, documents are collected to explore the use of music and the movement in teaching and learning mathematics (T\&L) in preschool.

The data collection methods used in this study were obtained through various sources for a variety of purposes including 1) observations (aimed at explaining in more detail the situations, events, interactions, and behaviors) 2) semi-structured interviews (aimed at attaining participants' statements about their experiences, attitudes, beliefs, and thoughts) and 3) document analysis (including children's work). According to Talib (2013), triangulation is a technique that uses two or more methods in data collection to study human behavior. Triangulation methods were employed to validate the findings of this study through interviews, observations and document analysis. Various sources of data enabled the researcher to gain high-quality qualitative data that provided a rich picture about the study (Ghazali \& Sufean, 2016).

The researcher used a semi-structured interview. This interview method was selected for the purpose of obtaining more information on music use and movement. The semi-structured interview method enables the researcher to process the semi structured interview questions based on the answers given by the study participants (Kothari 2004). This study incorporated observation of participants in the natural setting (i.e. the classroom in which the lesson was carried out). Observations of participant in the natural setting allowed for the exploration and 
understanding of the teaching and learning processes such as how music and movement are used in the teaching sessions.

The validation of the interview protocol was performed by three experts. Interview recordings were analyzed to obtain preliminary findings. The process of analysis is done after the interview is transcribed which covers themes related to music use and movement. All data were analyzed using Nvivo 12 Plus analysis software to generate themes to answer the research questions. Thematic analysis is used to analyze and interpret the data.

As this study involves video-recording during mathematics lessons, permission was obtained from both the teachers and the children. Consent letter were obtained from all participants that confirmed their participation as voluntary as well as permission to being video-recorded. Pseudonyms were used for all participants in this study. Also interviews were confidential.

\section{Findings and Discussion}

The themes emerged as a result of the analysis of the interviews, document analysis and observation can be categorized into: 1) children's attention and interest 2) children understanding and 3) emotional development of children.

\subsection{Help Attract Children's Attention and Interest}

One of the participants (i.e. GP2) describe the effect of music and movement as a result of using music and movement during her teaching session. “... Usually when we teach using music and movement it can attract children because music and movement are very close to children. So, these kids, we can see that they can pay attention to us when they sing songs and make movement during lessons...").

A photo taken during the observation provided evident for the claim made by the teacher. Figure 1 clearly shows the children's behavior as a result of the use of music and movement by the teacher.

The children paid full attention to the teacher. During this session, the lesson was about numbers. As the teacher was singing, she gestured with her hand the related numbers. For example, when it comes to number seven-she made the motion as she was holding a hook. As can be seen in Figure 1, everyone focused on what the teacher was doing (gesturing with her hand) and saying (i.e. singing). Not a single child played with their friends next to them, neither did their attention were distracted by other events happening in the surrounding. Clearly, the music (i.e. in the form of a song) and the movement (i.e. gestures) performed by the teacher in front of the classroom whilst singing help captured the children's attention to fully focus on the teacher.

More interestingly, children imitated what the teacher did. As can be seen in Figure 2, majority of the children did not only focus to the teacher and observed what the teacher did, they even followed the hand and finger movements demonstrated by the teacher. 


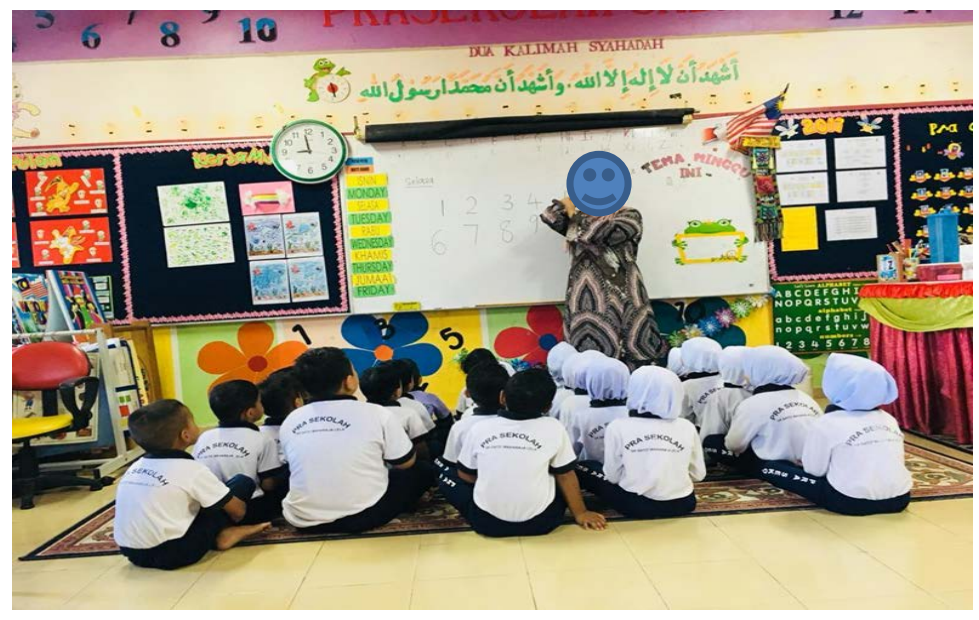

Figure 1. All children focused their attention to the teacher.

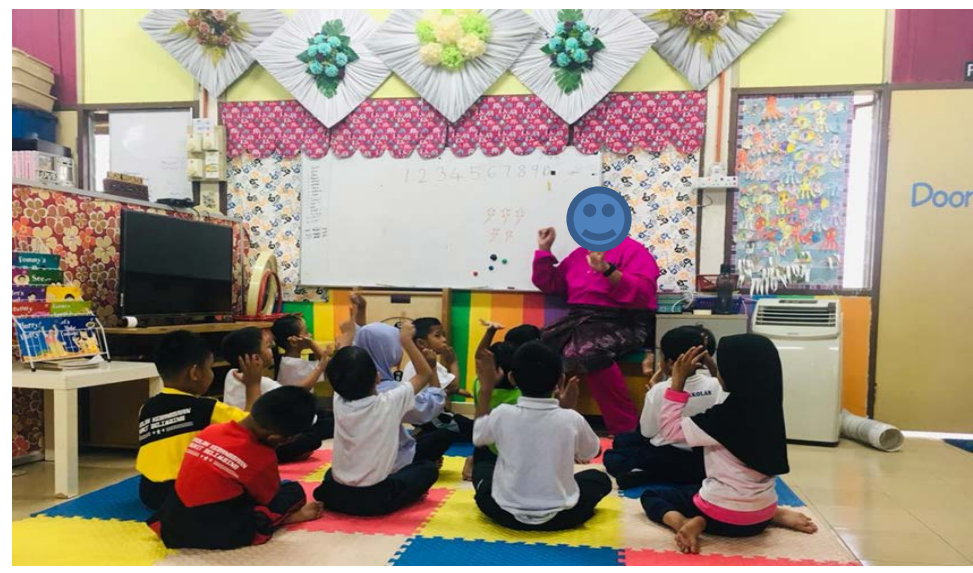

Figure 2. Children followed the teacher's gesture whilst singing.

“... Children are really interested in music and movement activities. When children are interested, indirectly students give us more focus..." (P3)

The third participant (P3) mentioned similar children's response when singing and movement were integrated during mathematics lesson. As P3 assert, children's interest in music influenced their focus. P3 further describe that children paid full attention in class when he performed the singing activity accompanied by making movements. Interestingly, the children showed great engagement and followed the movement demonstrated by the teacher and singing along with the teacher.

This is also supported by the fourth participant (P4) who stated that: "Throughout my 7 years of experience, we see these children.... when activities that involve movement and singing, they are more interested because I can see their attention as I teach..." (P4)

Aferonorain (2013) proves that interest is a driving force that stimulates students to pay attention to individuals, objects and activities. As evident in this study, it is the songs incorporated into that lesson that makes the children become attracted to pay attention to the teacher. When children focused on what 
the teacher were saying and doing, knowledge can be transmitted easily

The first participant described that the strong reason for using music and movement was because "Actually what drives me into using singing is... there is creative movement, I find this is one of the ways that increase students' interest in learning. That's why music is considered as an entertainment in the teaching and learning process because I believe that not only as a child, we as adults, find music as interesting" (P1). As P3 said "Most children love music. So, we use the method that is of children's interest". Clearly, teachers incorporated music and movements in classroom as this approach is connected with the children's interest. Furthermore, this is among the best means to tackle problems often happened at the beginning of the year involving young children who just entered the school. As asserted by P4 "At the beginning of the year, we try to use this approach-music and movement-very often ... because we want to entertain children, sometimes they don't want to go to school, feel scared, do not enjoy, have problems making friends, so here music and movement can help them get them interested to come to school."

It is often troublesome for young children in their first days entering school and separating from parents. Obviously, music help young children deals with difficult emotions (Miller \& Coen, 1994). By using music, teachers help children cope with negative feelings and slowly become adapt to the new environment and friends.

\subsection{Improve Children's Understanding}

The second participant (GP2) found that children were capable of answering posed questions number songs were used for introducing the mathematics concept "... the kids are able to learn quickly, when we ask questions, these kids will be able to answer and understand the concepts taught in the classroom ...”. Their understanding of the taught concept was also evident in their work.

As can be seen in Figure 3, the children work out the given task individually without any help from the teacher. Their engagement with the music (i.e. the song) and movement activities helped them work out the task. The children completed the worksheets given correctly after being introduced to the concept of time using music and movement.

Also when learning about numbers, children could grasp the number names easily when they recited the song and made the related movements. It is through singing aloud the number song several times that helped the children memorized the sequence of the number names easily and correctly.

In many mathematics topics, basic knowledge and skills such as basic numbers are often necessary and plays an important role when processing the mathematics. Teachers need to ensure this basic knowledge is mastered by the children before moving to other topics (Bakar, 2017). For example, counting skills is vital when children need to solve addition problems. Without mastering the basic counting skills, children are not capable of adding the quantities of the 


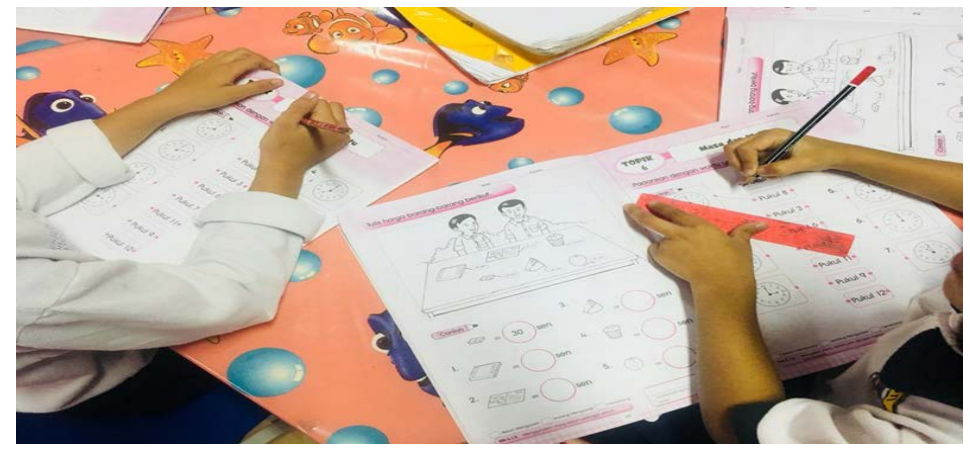

Figure 3. Children successfully worked out the worksheet without referring to peers or the teacher.

addends and reach the total. As evident in this study, music is proved to be one of the effective ways to help children understand and master basic number skills. Rhyme and rhythm (in song) highlight the sounds and syllables in words (Church, 2001) which help children to memorize numbers. Reciting the numbers in a fun way (i.e. through singing) seemed practical and had ease the children to memorize the number sequence. More importantly, the skills that children develop during music times and activities will last them a lifetime (Turner, 1999).

\subsection{Build Children's Emotional Development}

Majority of the participants emphasize how music and movement supported the emotional aspects of the children. Children enjoyed the moments when they recited the "Number song" and moving around.

"In terms of how we use music and creative movement, what I see most is the children's mood. So when we use music and creative movement I see the student's mood... They are more excited, and they wanted to try"... (GP1).

... "happy emotions come, children will calm down. Music and movement will make these kids happy and happy"... (GP2)

... "children have fun"... (GP3). The participants highlighted that children become excited, happy and they had fun.

As Jantan (2013) state music and movement is particularly helpful in assisting children's emotional development as these activities can be enjoyable and encourages children to communicate and interact with others. An important characteristic of music lies on its capability to arouse emotions (Hunter, Schellenberg, \& Schimmack, 2010). While there are sad songs that can trigger negative feelings, positive emotions often spark when educational music is employed in classrooms. Such emotions are critical for children's development as well as learning.

\section{Conclusion and Recommendations}

The findings of this study provide an initial overview and reference for teachers regarding the incorporation of music and movements in mathematics instruc- 
tion. This study found that singing and movement contributed to many positive aspects that facilitated mathematics learning including attracting the attention and focus of the children, supporting emotional development and understanding of mathematics concepts. Being evident that music and movement (in the form of songs and accompanying hand and body movements) benefited mathematics teaching and learning (e.g. cognitively and emotionally), it is strongly suggested that teachers diversify their approaches used for teaching mathematics by means of integrating music and movement activities particularly when introducing new concepts to the children.

This study has implication for teacher training. As there exists a link between music and movement with mathematics learning as evident in this study, it is suggested that teachers being provided with specific trainings relating to music and movement. Workshops or activities related to music and movement can be conducted at the school level to help preschool teachers improve their teaching practices. Further, sharing of teaching effective practices especially pertaining to the use of music and movement should not be limited among preschool teachers only but can also be expanded to teachers of higher grade levels.

Also, the use of music and movement requires creative and innovative teachers to enable diversity of efficient means used to help ease children's learning process. Rather than employing traditional approaches, teachers should flexibly use new and creative ways to engage children in learning. Various parties need to work together to help realize the goals of the Malaysian Education Development Plan 2013-2025 to improve the quality of preschool education towards preparing children for present and future life. It is therefore vital to train teachers on effective ways to use music and movement in all aspects of teaching and learning. In addition, it is anticipated that the teaching and learning processes will be interesting and engaging with the variety of music and movement activities used in classroom.

\section{Funding}

This research was supported by the Faculty of Education, Universiti Kebangsaan Malaysia code PP-FPEND-2019.

\section{Conflicts of Interest}

The authors declare no conflicts of interest regarding the publication of this paper.

\section{References}

Abdullah, N., Halim, L., \& Zakaria, E. (2014). Vstops: A Thinking Strategy and Visual Representation Approach in Mathematics Word Problem Solving toward Enhanching STEM Literacy. Eurasia Journal of Mathematics, Science \& Technology Education, 10, 165-174. https://doi.org/10.12973/eurasia.2014.1073a

Aferonorain (2013). Keberkesanan Kaedah Nyanyian Dalam Meningkatkan Daya Ingatan Murid Tahun 4.

Arshad, M. (2012). Pendidikan literasi awal kanak-kanak. Teori dan amali. Perak: Penerbit 
Universiti Pendidikan Sultan Idris.

Azuan, A. (2003). Keyakinan Guru-guru Program Pensiswazahan Kursus Perguruan Lepasan Diploma, Mengajar Sains Tulen Dan Matematik Tambahan Dalam Bahasa Inggeris. Malaysia: Universiti Teknologi Malaysia.

Bakar, K. A. (2017). Young Children's Representations of Addition in Problem Solving. Creative Education, 8, 2232-2242. https://doi.org/10.4236/ce.2017.814153

Bilhartz, T. D., Bruhn, R. A., \& Olson, J. E. (1999). The Effect of Early Music Training on Child Cognitive Development. Journal of Applied Developmental Psychology, 20, 615-636. https://doi.org/10.1016/S0193-3973(99)00033-7

Campbell, P. (2010). Music in the Culture of Children. This Thing Called Music: Essays in Honor of Bruno Nettl. New York: Rowman \& Littlefield Publishers.

Church, E. B. (2001). The Math in Music and Movement. Early Childhood Today, 15, 38-43.

Cross, C. T., Woods, T. A., \& Schweingruber, H. (2009). Mathematics Learning in Early Childhood: Paths toward Excellence and Equity. Washington DC: National Academies Press.

Deasy, R. J. (2002). Critical Links: Learning in the Arts and Student Academic and Social Development. Washington DC: Arts Education Partnership.

Elizabeth, A. O. (2016). The Interrelation between Music Education and Cultural Education in Early Childhood Music Education in Kenya. International Yearbook for Research in Arts Education.

Ells, L., Ogilvie, J., Kurtz, R., Temply, J., Moore, H., McLure, S., \& Shucksmith, J. (2009). North East Dance \& Health Project: An Evaluation of a Creative Dance Programme in Preschool Children. Stockton on Tees, Stockton South: North East Public Health Authority.

Elofsson, J., Gustafsson, S., Samuelsson, J., \& Träff, U. (2016). Playing Number Board Games Supports 5-Year-Old Children's Early Mathematical Development. The Journal of Mathematical Behavior, 43, 134-147. https://doi.org/10.1016/j.jmathb.2016.07.003

Gallotta, M. C., Baldari, C., \& Guidetti, L. (2017). Motor Proficiency and Physical Activity in Preschool Girls: A Preliminary Study. Early Child Development and Care, 4, 1-11.

Garaigordobil, M., \& Berrueco, L. (2011). Effects of a Play Program on Creative Thinking of Preschool Children. The Spanish Journal of Psychology, 14, 608-618. https://doi.org/10.5209/rev_SJOP.2011.v14.n2.9

Gasteiger, H. (2012). Fostering Early Mathematical Competencies in Natural Learning Situations-Foundation and Challenges of a Competence-Oriented Concept of Mathematics Education in Kindergarten. Journal Für Mathematik-Didaktik, 33, 181-201.

https://doi.org/10.1007/s13138-012-0042-x

Ghazali, D., \& Sufean, H. (2016). Metodologi Penyelidikan Dalam Pendidikan (2nd ed.). Penerbit UM.

Hunter, P. G., Schellenberg, E. G., \& Schimmack, U. (2010). Feelings and Perceptions of Happiness and Sadness Induced by Music: Similarities, Differences, and Mixed Emotions. Psychology of Aesthetics, Creativity, and the Arts, 4, 47-56. https://doi.org/10.1037/a0016873

Jantan, R. (2013). Faedah bermain dalam kalangan kanak-kanak (4-6 tahun). Trend dan isu pengajaran dan pembelajaran, 1, 59-69.

Kothari, C. (2004). Research Methodology: Methods and Techniques. New Delhi: New Age International (P) Limited.

Lobo, Y. B., \& Winsler, A. (2006). The Effects of a Creative Dance and Movement Pro- 
gram on the Social Competence of Head Start Preschoolers. Social Development, 15, 501-519. https://doi.org/10.1111/j.1467-9507.2006.00353.x

Marsh, K., \& Young, S. (2016). Musical Play. In G. McPherson (Ed.), The Child as Musician: A Handbook of Musical Development (2nd ed., pp. 462-484). Oxford, UK: Oxford University Press.

Marshall, C., \& Rossman, G. B. (2011). Primary data collection methods designing qualitative research. Los Angeles, CA: Sage Publications.

Miller, A., \& Coen, D. (1994). The Case for Music in the Schools. Phi Delta Kappan, 75, 459-462.

NCTM (National Council of Teachers of Mathematics) (2008). Curriculum Focal Points for Prekindergarten through Grade 8 Mathematics.

Östergren, R., \& Träff, U. (2013). Early Number Knowledge and Cognitive Ability Affect Early Arithmetic Ability. Journal of Experimental Child Psychology, 115, 405-421. https://doi.org/10.1016/j.jecp.2013.03.007

Pica, R. (2006). Physical Fitness and the Early Childhood Curriculum. Young Children, $61,12$.

Pollatou, E., Karadimou, K., \& Gerodimos, V. (2005). Gender Differences in Musical Aptitude, Rhythmic Ability and Motor Performance in Preschool Children. Early Child Development and Care, 175, 361-369. https://doi.org/10.1080/0300443042000270786

Ramani, G. B., \& Siegler, R. S. (2008). Promoting Broad and Stable Improvements in Low-Income Children's Numerical Knowledge through Playing Number Board Games. Child Development, 79, 375-394. https://doi.org/10.1111/j.1467-8624.2007.01131.x

Ramani, G. B., \& Siegler, R. S. (2011). Reducing the Gap in Numerical Knowledge Between Low- and Middle-Income Preschoolers. Journal of Applied Developmental Psychology, 32, 146-159. https://doi.org/10.1016/j.appdev.2011.02.005

Rauscher, F. H., Shaw, G. L., Ky, K. N., \& Wright, E. L. (1994). Music and Spatial Task Performance: A Causal Relationship. Los Angeles, CA: The American Psychological Association 102nd Annual Convention.

Rosli, R., Goldsby, D., \& Capraro, M. M. (2015). Using Manipulatives in Solving and Posing Mathematical Problems. Creative Education, 6, 1718.

Trainor, L. J., \& Cirelli, L. (2015). Rhythm and Interpersonal Synchrony in Early Social Development. Annals of the New York Academy of Sciences, 1337, 45-52.

https://doi.org/10.1111/nyas.12649

Talib, O. (2013). Asas Penulisan Tesis Penyelidikan dan Statistik. Serdang: Universiti Putra Malaysia.

Turner, M. E. (1999). Child-Centered Learning and Music Programs: Child-Centered Learning in Music Programs for Young Children Can Foster Their Emotional, Social, Cognitive, and Musical Development. Music Educators Journal, 86, 30-51. https://doi.org/10.2307/3399574

Yaakob, Z. (2007). IPTHO Pendidikan Muzik Prasekolah. Batu Pahat, Johor.

Yunus, F. (2014). Cross-Cultural Adaptation of Developmental Criteria for Young Children: A Preliminary Psychometric Study. International Education Studies, 7, 130-145. https://doi.org/10.5539/ies.v7n13p130 